\title{
6. Reporting war: Covering the Pacific - Radio NZ International and West Papua as a case study
}

\section{COMMINTARX}

Publicly funded, Radio New Zealand International has a broadcasting role that is not ratings-driven; it has no circulation figures or advertising revenue to worry about. The broadcaster's work is simply to produce the first draft of history. Or, as the advertisement of a national television network in New Zealand says, 'It's all about the story'. This commentary was one of a series in a panel of journalists at the Reporting War conference, jointly organised by the International Committee of the Red Cross (ICRC) and Massey University's Department of Communication, Journalism and Marketing in Wellington on 22 May 2009.

Keywords: Bougainville war, conflict reporting, foreign correspondent, insurgencies, propaganda, public broadcasting

WALTER ZWEIFEL

Radio New Zealand International, Wellington

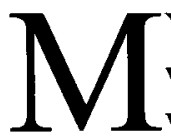

CONTRIBUTION to this conflict reporting debate relates to working at Radio New Zealand International whose role is somewhat unusual as it is a public broadcaster based in Wellington, but carrying mainly news about Third World Pacific island states to mainly Third World audiences in the region.

Publicly funded, we are in a situation that is not ratings-driven; we have no circulation figures or advertising revenue to worry about. Our work is simply to produce the first draft of history. Or, as the ad of a national television network in New Zealand says, 'It's all about the story', although I personally wonder whether that quote couldn't be reprinted on a Tui beer billboard to give some added effect. 


\section{Pacific region conflicts}

In recent decades in the Pacific region there has been no conflict on the scale of the carnage seen during World War II. The latest wars have had no cruise missiles, no tanks and, mercifully, no cluster bombs or land mines. What lingers is an insurgency in the western half of New Guinea, now referred to as Papua or West Papua. The other prolonged recent armed conflict in the region was the war on the Papua New Guinea island of Bougainville, which was stopped with a truce in 1997 and formally ended with a peace ceremony in 2001 in Arawa which I attended as the only journalist from New Zealand.

Internationally, these two conflicts have been of little interest. The main reason for this is, I believe, the absence of First World protagonists, most notably, Anglo-Saxons.

We at Radio New Zealand International have been reporting on these conflicts for the simple reason they took place within our loosely defined reporting patch. They are also within the target area of our broadcasts. May I add that we exclude East Timor, or Timor-Leste, from our brief, in part because of a lack of resources.

The Papua issue is complex and the grievances are numerous. At the heart is a UN-approved referendum in 1969 which paved the way for Indonesia to take over the former Dutch colony. The drive for independence in West Papua however precedes the referendum, which is known as the Act of Free Choice or, as some of the losers call it, possibly correctly, the Act of No Choice.

The Free Papua Movement, or OPM, has been involved in an unsuccessful military struggle whose end is not in sight. The conflict has led to prolonged misery and abuse that has cost the lives of tens of thousands of people. Today, raising the separatist Morning Star flag can result in a longer prison sentence than a conviction for manslaughter in New Zealand.

For the international community, the matter appears to be largely settled as those problems are an internal affair for Indonesia to resolve. With concessions for autonomy after the demise of the Suharto regime, the Papua issue has practically vanished from the international scene.

We get information about newsworthy developments nowadays most often via email. Human rights groups, pressure groups, and churches, tend to alert us to what is happening. At times, we pick through English-language Indonesian websites for information. On some occasions we've been emailed pictures 


\section{REPORTING WARS}

or even video footage that corroborates reports of rallies or marches. Verification though, is difficult - often we rely on human rights organisations, like Elsham, for details. After the [April, 2009] mutiny by Indonesian soldiers in Jayapura, we were quite lucky as we got through to the reporter of the Antara news agency, who happened to be in the area at the time of the disturbance.

Years ago, we dealt with the ICRC over a mysterious hostage situation which was resolved in an operation that saw the use of European elite forces and, most controversially, a white helicopter. The inference at the time was that its colour misled the hostage-takers to believe they were dealing with the Red Cross. The confusion damaged the ICRC's reputation and it took quite an effort for it to regain the trust it had enjoyed.

Over the years, we've also covered the spillover of the conflict across the only land border of any Pacific Island country, that is into Papua New Guinea. Communications are difficult and, often, we end up talking to, for example, the Catholic church in Vanimo. This is, in part, because the church ends up looking after the border-crossers or refugees.

\section{Bougainville}

Let me turn to the Bougainville civil war of the 1990s. Information was patchy and often unreliable. Through its office in Solomon Islands, the separatist Bougainville Interim Government used to send us faxes. Most often we ignored them because the claims appeared too far-fetched. But we did tell them that we were going to carry their side of the story if they provided us, not with outlandish propaganda, but with credible information.

Being one of the few stations dealing with the Bougainville crisis, we were also one of the stations listened to via shortwave. And, as it was in the interest of the separatists to be heard, a relationship developed where we felt that we were given usable information.

Media access to Bougainville was always very limited. When I was at a conference in Port Moresby in 1995, I met a young reporter, Peter Niesi, who was based in Rabaul. His round involved regular trips on behalf of the Post-Courier to Bougainville. As far as I know he was, for quite some time, the only journalist to be able to go to the military-held areas and the BRA rebel zone.

He spoke about the need to be absolutely accurate in his reporting. For him, his life depended on that. Through Peter, we received regular updates whenever he made it back to Rabaul. 
At the time, the Solomon Islands government was alarmed at the spill-over of the conflict into the Shortland Islands. We were advised by listeners that the 8 am relay of our news bulletin in Honiara was at times jammed. In response to that, we started to put the usual daily Bougainville story, no longer at the top of the Pacific news, but at random in the line-up, in the hope of tricking whoever was trying to interfere with the local relay.

Solomon Islands' criticism of the Papua New Guinea military activity was pronounced. To balance the information flow in early 1997, we secured a long phone interview with PNG prime minister Sir Julius Chan, who restated his government's position.

In the middle of the conversation, he stopped to say that [then Australian Prime Minister John] Howard was on the other line but that he could wait. A day later it transpired Howard had just heard about the arrival of Sandline mercenaries in PNG. In my interview, Sir Julius had obviously withheld key information and I had no clue that I should ask him about plans to get South African fighters to deal with the Bougainville Revolutionary Army (BRA). Within days, the outcry over the Sandline affair ended Sir Julius' career as prime minister.

\section{Conclusion}

As these examples illustrate, the information we got and get is patchy, but we do endeavour to get it right. This means we tend to err on the side of caution. An example is the 2000 Solomon Islands' coup when a gunboat with Malaitans onboard shelled the Guadalcanal coast. Figures of hundreds of deaths were being bandied about: CNN quoted an academic as saying, 70 people had been killed. We didn't run a death toll and [later] had a Red Cross confirmation that just two people had died.

Walter Zweifel, news editor at Radio New Zealand International, has been the reporting backbone of the station since 1994. He has a specific interest in West Papua, a region that, as a journalist, he has been unable to gain access to. Prior to joining RNZ International, he worked for Swiss Radio International. Zweifel has also served in the Swiss military.

walter.zweifel@radionz.co.nz 
Copyright of Pacific Journalism Review is the property of Auckland University of Technology and its content may not be copied or emailed to multiple sites or posted to a listserv without the copyright holder's express written permission. However, users may print, download, or email articles for individual use.

http://www.aut.ac.nz/depts/commstud/journ/pjrsubs.shtml 